\title{
VISUAL POETRY OF UKRAINIAN-CANADIAN ÉMIGRÉ LITERATURE
}

\section{Nakashydze I. S.}

\section{INTRODUCTION}

Visual (concrete) poetry is the original part of the poetic art that can be positioned as the synthesis of literature and fine arts. It took a position as poetry of objectivity.

Visual poetry has a long, complicated and contested history. However, for most scholars considered the emerge of contemporary concrete and visual poetry just before the official "International Concrete Poetry Movement" (1955-1970) with the works of Mallarmé and others involved in various Avant Garde movements interested in materialist aesthetics (such as Cubism, Dadaism, Vorticism, and Futurism). Obviously the birth of concrete poetry did not happen ex nihilo, and even the "creators" of the genre acknowledged their "predecessors": Mallarme, Pound, Joyce, Cummings, and Apollinaire from literature; Mondrian and Max Bill from painting; Eisenstein from cinema; Webern from music ${ }^{1}$.

In 1952 three poets in Sao Paulo (Brazil) - Haroldo de Campos, Augusto de Campos and Decio Pignatari - formed a group for which they took the name "Noigandres". In the first half of 1953 Augusto de Campos wrote the first systematic set of poems which gave body to the new formal concept: a series of poems entitled "Poetamenos" inspired by the "Klangfarbenmelodie" ("Tone-Color Melodies") of Anton Webern.

The poems from "Poetamenos" are intended for both eye and ear. The colors function as directions for reading (male and female voices in "eis os sem senão os corpos") and to designate word themes. It occurred to Augusto de Campos to use "luminous letters which could automatically switch on and off as in street advertisements" in the presentation of the "Poetamenos" poems, "but there was no money" so he used colors instead ${ }^{2}$.

All definitions of concrete poetry can be reduced to the same formula: form $=$ content $/$ content $=$ form . Individual poets tend to say this in less general terms to suit their own solutions of the form-content problem. Concrete poem is an object in and by itself not an interpreter of exterior

1 Pineda V. Speaking About Genre: the Case of Concrete Poetry. URL: http://www.ubu.com/papers/pineda.html.

${ }^{2}$ Solt M.E. Brazil. URL: http://www.ubu.com/papers/solt/brazil.html. 
objects and/or more or less subjective feelings. Its material: word (sound, visual form, semantical charge); its problem: a problem of functionsrelations of this material ${ }^{3}$.

If to speak about visual poetry in Ukraine it is difficult to establish exactly when it originated, but its introduction was unquestionably connected with the conversion of Kyivan Rus to Christianity in 988. The first examples of visual texts are presented in St. Sophia Cathedral in Kyiv, which was founded at the height of Kyivan Rus's power under the rein of Prince Jaroslav the Wise in 1037. Some of the graffiti in the St. Sophia Cathedral are framed; others are decorated with a cross; artistically done images of prelates or saints and symbolic signs as well as less frequent drawings of warriors, birds and animals.

Next wave of visual poetry was during baroque age in the late 17th-beginning 18th centuries. Some scientists prefer to call this poetry visual, later - concrete that can be analyzed in the context of visual ${ }^{4}$.

One of baroque poets of this period is Ivan Velychkovskyj - Ukrainian writer, poet, translator, literary theorist, cultural and public figure, priest. Example of his visual poem is given in figure 1.

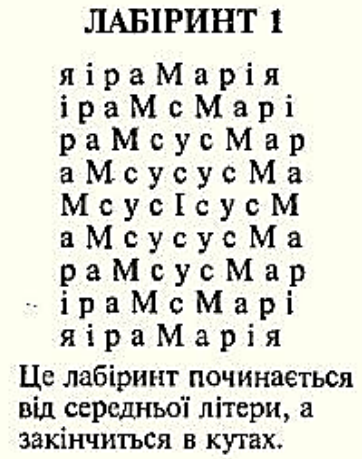

ЛАБІРИНТ 1

я i p a $\mathrm{M}$ a $\mathrm{p}$ i

ip a $M$ c M a p i

pa $M$ c yc $M$ a p

a $\mathrm{Mcyc}$ y $\mathrm{M}$ a

$\mathrm{McycI}$ c y c M

a $M$ c y c yc $M$ a

pa $M$ c y c M a p

ip a $\mathrm{M} \mathrm{c} \mathrm{M} \mathrm{a} \mathrm{pi}$

я i p a $\mathrm{M}$ a $\mathrm{p}$ я

Це лабіринт починається

закінчиться в кутах.

\section{ЛАБІРИНТ 2}

I c y c M c y c I

c y c $M$ a $M$ c y $c$

y c $M$ a p a $M$ c y

c M a pipa M c

$\mathrm{M}$ a $\mathrm{p}$ i $я$ i $\mathrm{p}$ a $\mathrm{M}$

$c \mathrm{M}$ a p i a M c

yc $M$ a a $M$ c y

c y c M a M y c

I c y c M o y c I

Цей лабіринт починається

3 чотирьох кутів, а

закінчуеться посередині.

\section{Fig. 1. I. Velychkovskyj. Labyrinth ${ }^{5}$}

In general Ukrainian contemporary visual poetry is not far behind the new wave of the global visual poetry. Mostly interest in visual experiments

\footnotetext{
3 Solt M.E. Concrete Poetry a World View. URL: http://www.ubu.com/papers/ solt/intro.html

${ }^{4}$ Pochynok Yu. Concrete poetry: poetry of fact as a connection between letters and thing. Spheres of Culture. 2012. Vol. 1. P. 82-89.

${ }^{5}$ Величковський I. Твори. Київ : Наукова думка, 1972. 191 с.
} 
was associated with Ukrainian futurism of $1920-1930^{\text {th }}$, especially their chief mastermind M. Semenko. Years of socialist realism, unfortunately, interrupted its natural development - visual poems were declared hostile to the proletarian culture formalism, and their creators disadvantaged. In 1960s appears shoots of new visual poetry in the works of such authors as Mykola Holodnyj, Vladimir Luchuk, Mykola Miroshnichenko, Anatoly Moisienko, Ivan Iov etc., but these experiments on the word until the end of the eighties are mainly drafts with the reader.

\section{Visual poetry in Ukrainian poetry in Canada. M. Soroka's poems}

Actively development of Ukrainian visual poetry took place outside of Soviet Union, particularly in Canada. Only after Ukraine's independence in 1991 the writers were able to roam freely in the realm of visual poetry. The aim of this paper is to analyze visual poetry in Ukrainian émigré poetry in Canada as a new form of word expression. Among the most well-known authors is Yars Balan, Mykola Soroka, Brian Dedora, Andrew Suknaski etc.

It is worth mentioning that Ukrainian visual poetry in North America reflects more than one lexical-grammatical variant of the Ukrainian language. Ukrainian of the Canadian and American Ukrainian community is based on the so-called Western variant of Ukrainian which differs phonetically, grammatically, stylistically, and lexically from variant which is used by the population of Ukraine nowadays.

The same variant of Ukrainian is used by prewar emigrants and those who left the country during World War II, while most recent emigrants, who left Ukraine in the 1970s or later tend to follow standards which are established on the territory of contemporary Ukraine. Authors from Ukraine successfully develop forms of visual poetry which require the production of semantically complex and coherent poetic texts (palindromes, acrostics, "crabs", pattern poems, rebuses). For Ukrainian-Canadian poets, who was born and raised in a predominantly non-Ukrainian environment, English is the main language of communication, and Western culture is a far more influential factor informing creative orientation than ethnic heritage.

The achievements of Canadian visual poets of Ukrainian descent, however, can be described to two main factors: the international revival of the genre in 60-70s which has stimulated the experimentations of bpNikol, Earle Bimey, Bill Bissett, Stephen Scobie, and other Canadian practitioners, as well as interest in their ethnic heritage. The Canadian poems present a helpful microcosm (with unique influences, traditions, and understandings of such works) of a wider, transnational poetic movement. Of course, international influences and ongoing poetic interactions influence the 
Canadian poets, and they in turn add to ongoing transnational developments in visual poetry and other experimental poetries ${ }^{6}$.

Ukrainian practitioners of visual poetry, such as Mykola Soroka, whose area of research is the Ukrainian visual poetry of medieval and Baroque times, are attempting to theorize on the subject, although their contribution in most cases is limited to prefaces to anthologies, brief surveys in popular journals and newspapers, as well as short entries on visual poems and related issues in library dictionaries and encyclopedias.

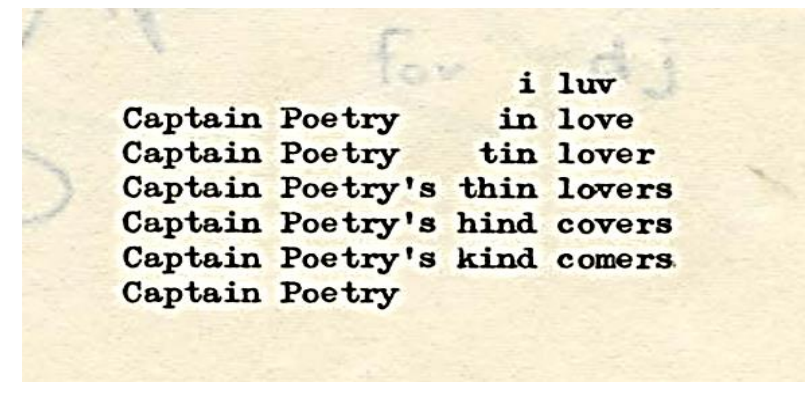

Fig. 2. bpNikol. Captain poetry in love (fragment) ${ }^{7}$

Visual poets can be distinguished by the radicalization of the means of communication and be differentiated from other experiences for not semantic values. Graphic-phonetic relations and the substantive use of space as an element of composition maintain a simultaneous dialectic of eye and voice. The space in the concrete poetry plays an important role in the normal arrangement of letters or drawings that builds a complete picture association.

Visual poets of the second half of $20^{\text {th }}$ - beginning of $21^{\text {st }}$ century produced a fundamentally different understanding of language and visual image as a means of transmission of the poetic message. Lack of syntactic relations and word offset degradation in visual quality, acting as components of formation of content and form ${ }^{8}$.

Baroque experience is very useful in consideration of contemporary visual poetry and even makes it more interesting. It is connected with the fact that every new period of development is another and is the step forward. For example, M. Soroka's poem "Pjata kolona" ("The Fifth column")

\footnotetext{
${ }^{6}$ Nazarenko T. Contemporary visual poetry in Russian and Ukrainian: a critical study. Edmonton, 1999. 365 p.

${ }^{7}$ BpNikol. The Captain Poetry Poems. Vancouver : Blewointment Press, 1971. 25 p.

${ }^{8}$ Polishchuk N. Spotting poetry second half of this stage: "Periodic system of words" Ivan Iov. URL: http://www.khnu.km.ua/root/res/2-7295-41.pdf.
} 
(figure 3) is close to verses-labyrinths by I. Velychkovsky in form, but has the different meaning. "The Fifth column" is structured as a ten line composition in which the first four columns consist of the Ukrainian letter $\boldsymbol{i} e$ while the fifth column presents a vertical succession of the letter of the Russian alphabet which corresponds to the sound $\boldsymbol{e}$. This work is composed as a visual metaphor of the trite verbal metaphor "fifth column" meaning any group of hostile infiltrators or an enemy in one's midst. In Soroka's piece the metaphorical meaning of the expression used as a title is exemplified literally on the visual level by the attempted letter arrangement.

\section{П'ЯТА КОЛОНА \\ ЕЄСЄЭ \\ ЕЄЕЄЭ \\ СЕЄЕЭ \\ СЕЄЕЭ \\ ЕЄЕЄЭ \\ СЕЄ ЭЭ \\ ЕЄСЕЭ \\ ЕСЕЄЭ \\ СЕЄЕЭ \\ СЕЄЕЭ}

Fig. 3. M. Soroka "Pjata kolona" ("The Fifth column")"

In general, such visualization of verbal metaphors is not very common in Soroka's compositions, in which the relations between the visual and the verbal messages are not so direct. In his logo-like poem "Dynamika $X X$ st?" ("Dynamics of the 20th century") (figure 4) the poet reinterprets and reconstructs one unit of communication, which is semantically neutral, into another one with a strong emotive connotation ${ }^{10}$. M. Soroka recalls tragic events of $20^{\text {th }}$ century in Ukraine: Holocaust, World War II, totalitarianism with its repressions etc. Here we can see crosses symbolizing both the twentieth century and death, and the coat of arms of the Soviet Union as the culprit.

\footnotetext{
${ }^{9}$ Nazarenko T. Contemporary visual poetry in Russian and Ukrainian: a critical study. Edmonton, 1999. 365 p.

${ }^{10}$ Nazarenko T. Contemporary visual poetry in Russian and Ukrainian: a critical study. Edmonton, 1999. 365 p.
} 


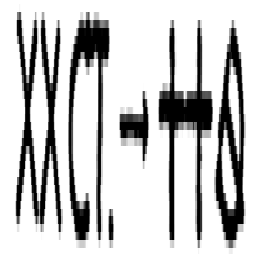

Fig. 4. M. Soroka "Dynamika XX st?" ("Dynamics of the 20th century") 11

M. Soroka often places poem lines in different contours (in the form of stairs, female breast, tea cap etc.).

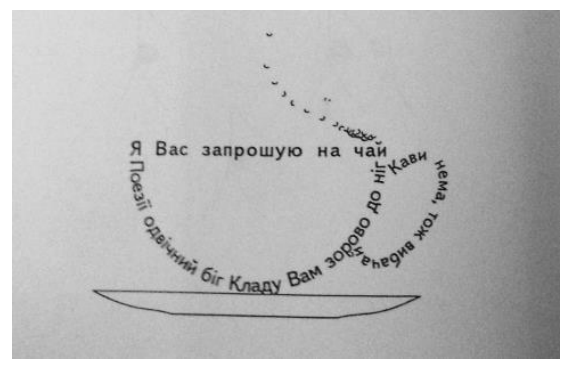

Fig. 5. M. Soroka. Untitled ${ }^{12}$

One of the few examples of visual pastiche in contemporary Ukrainian visual poetry is Soroka's "Moia cablepoema druzhyni" ("Cablepoem to My Wife") that is structurally modeled on the first card of M. Semenko's "Cablepoema za ocean" ("Cablepoem Across the Ocean") - a composite unit, which consists of eight separate cards, each delivering dynamic and panfuturists' messages throughout the world. In preserving the general design, lined dispatch of Semenko's pattern Soroka has radically changed its content. He leads the reader through the lyrical narrative of his personal feelings as well as his brief recollections on the flight across the Atlantic Ocean.

Soroka does not send his message to "everyone - everyone - everyone", as Semenko did, but clearly names his addressee by naming her three times; once directly, once in an acrostic arrangement of bold letters on the right

\footnotetext{
${ }^{11}$ Nazarenko T. Contemporary visual poetry in Russian and Ukrainian: a critical study. Edmonton, 1999. 365 p.

12 Хрестоматія 3 української літератури в Канаді: 1897-2000 / упор. : Яр Славутич та М. Шкандрій. Едмонтон : Видавничий комітет «Слова», 2000. 632 с.
} 
panel of the poem, and once in English transliteration at the bottom right comer. The typography of the poem also accentuates the lyrical character of the message, much of the text is written in delicate and fragile letters that have nothing in common with Semenko's aggressive bold typeface.

\section{Jars Balan's visual poems}

Contemporary Canadian poets of Ukrainian or mixed descent (Brian Dedora, Jars Balan and Andrew Suknaski) while reducing the usage of language, simultaneously tend to minimize the linguistic experiments by shifting the main symbolic and semantic emphasis from textual to visual and graphical components. Ukrainian letters, separate words or inscriptions, and, less frequently, sentences are employed as structural elements of visual compositions or collages ${ }^{13}$. In some works, like Jars Balan's "Hutsulam" ("To the Hutsuls") (figure 6), the use of language may be minimized to the point where the work looks like a geometrical composition - created in the style of Western Ukrainian ornamentation by a handful of recognizable Ukrainian letters and punctuation marks.

Sometimes Jars Balan minimizes letter element for example in poem "Tyha nich" ("Silent night") (figure 7). Here the quietness of night is visually symbolized by the conglomeration of soft signs that don't correspond to any speech sounds in Ukrainian language, but are used in orthography for marking the soft pronunciation of consonants.

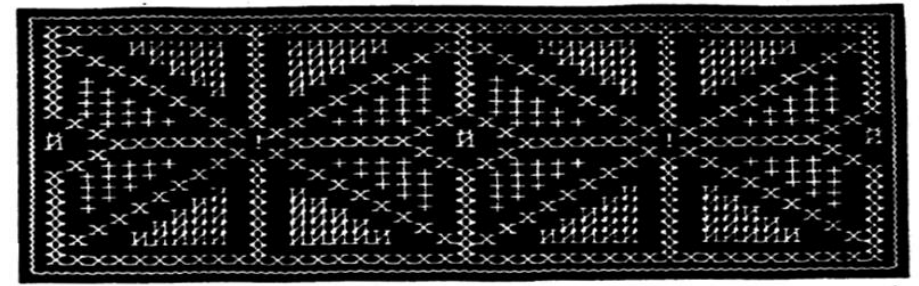

Fig. 6. Jars Balan "Hutsulam" ("To the Hutsuls") 14

\footnotetext{
${ }^{13}$ Nazarenko T. Contemporary visual poetry in Russian and Ukrainian: a critical study. Edmonton, 1999. 365 p.

${ }_{14}$ Nazarenko T. Contemporary visual poetry in Russian and Ukrainian: a critical study. Edmonton, 1999. 365 p.
} 


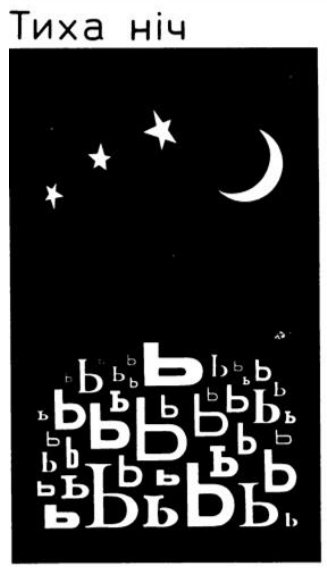

Fig. 7. Jars Balan "Tyha nich" ("Silent night")

The similar principle is in Maria Shun's poems. She gives her visual poems like illustration to book and names them "compositions". In their center - letters, from which the words are written in a spiral way so the reader can read poem from every word with different emotional color. Like in "Composition ZH": "zhinka zharije zhovtym zholudem" ("woman heats with yellow acorn") (figure 8).

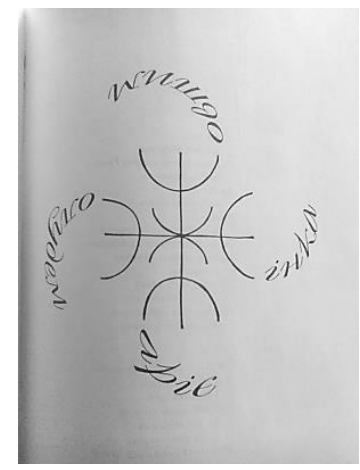

Fig. 8. Maria Shun "Kompozytcia ZH" ("Composition ZH") ${ }^{16}$

15 Балан Я. Визуальное. Черновик. 1999. № 14. URL: http://www.chernovik.org/ main.php?nom=14\&first=18\&cont=yes.

${ }^{16}$ Шунь М. Верлібріарій. Абетка : вірші. Київ : Факт, 2006. 405 с. 
Much of Balan's recently-produced visual poetry in both Ukrainian and English is based on personalized form of letters and typographical signs. The use of anthropomorphized letters initially appeared in Balan's series "Avtobiografika" ("Autobiography") (figure 9). This method is commonly used in advertisements and children's literature.

The entire Balan's work is based on the Cyrillic letter ia (a backward "R"), which in Ukrainian corresponds to the personal pronoun "I" and to the initial letter of the name Jaroslav (Jars) in its Ukrainian transcription.

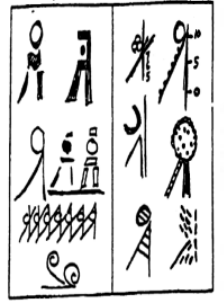

a)

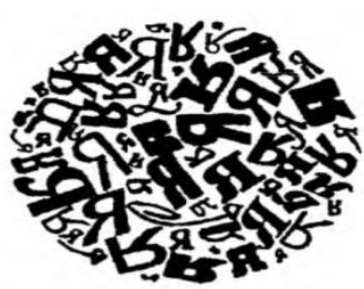

b)

Fig. 9. Jars Balan Series "Avtobiografika" ("Autobiography") ${ }^{17}$

In Figure $9 \mathrm{~b}$, the shape of the circle points to a metaphor for the integrity of the individual. Also Jars Balan's visual poems with letter "Ja" are psychological, as pronoun "I" means personality, individuality, like in the cycle Ballet (figure 10). Here we can see lots of people, that are individualities. There is also a gender aspect, which is expressed in the coloring of the letter.

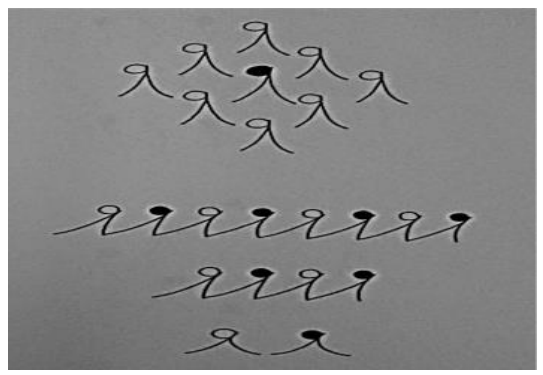

Fig. 10. Jars Balan "Ballet" (fragment) ${ }^{18}$

17 Хрестоматія 3 української літератури в Канаді: 1897-2000 / упор. : Яр Славутич та М. Шкандрій. Едмонтон : Видавничий комітет «Слова», 2000. 632 с.

18 Хрестоматія 3 української літератури в Канаді: 1897-2000 / упор. : Яр Славутич та М. Шкандрій. Едмонтон : Видавничий комітет «Слова», 2000. 632 с. 
Jars Balan also plays with different forms of personal pronouns in poem "Creed of western individualist" (figure 11) in the form of pyramid that refers to egocentrism and desire to have more and more.

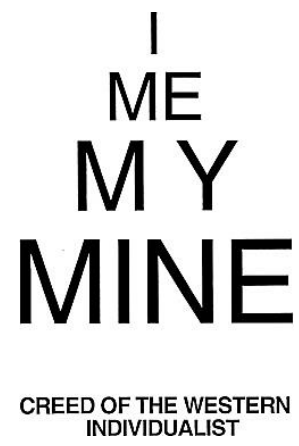

Fig. 11. Jars Balan "Creed of western individualist"

\section{Visual poetry of Ukrainian-Canadian contemporary poets}

Visual expression in Brian Dedora's "Vin vorukhnuvsia" ("He moved") (figure 12) is an exception in the Ukrainian-Canadian trend of minimalizing the usage of Ukrainian. His poem consists of nine panels or leaves, each offering an evolutionary movement of a repeated text. It doesn't contain any structural elements other than the basic textual configuration. In fact, four panels out of the nine are not obviously composed as visual texts.

Brian Dedora presents the same poetic text in its Ukrainian and Gaelic variants, arranged in two columns in the first panel. As a result of text manipulations, the sequence of nine panels composes a dynamic visual and highly metaphorical image ${ }^{20}$. Thus, in subtext there appears problem of child's language identity in mixed marriages in Canada. The visible dynamism of the poem is achieved in a way that is similar to the cinematographic technique of producing moving images out of static frames. On figure 12 is the first panel of the poem.

19 Балан Я. Визуальное. Черновик. 1999. № 14. URL: http://www.chernovik.org/ main.php?nom=14\&first=18\&cont=yes.

${ }^{20}$ Nazarenko T. Contemporary visual poetry in Russian and Ukrainian: a critical study. Edmonton, 1999. 365 p. 
the definite articles are spelled without an "e" in the orthographic style commonly associated with Bissett.

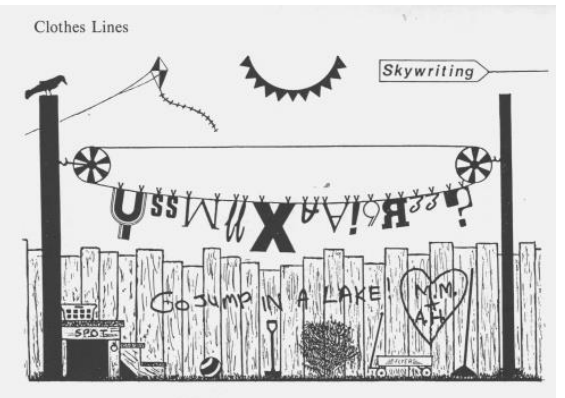

Fig. 13. Jars Balan "Clothes lines"24

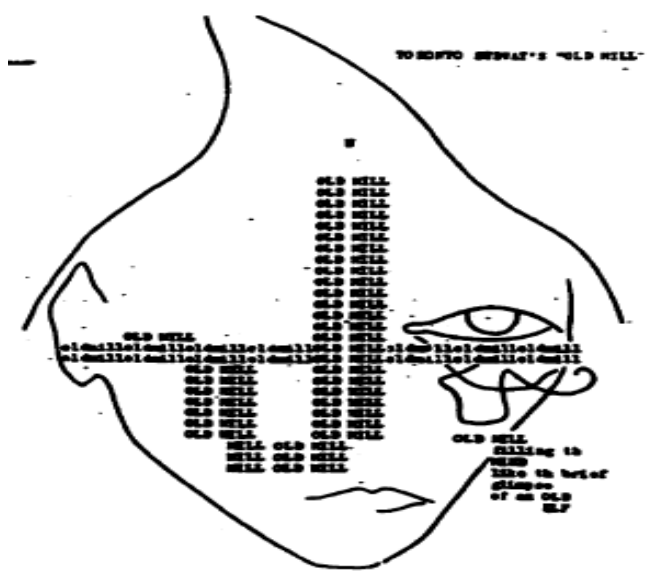

\section{Fig. 14. Andrew Suknaski "Toronto's Subway «Old Mill»",25}

Another noteworthy example of a linguistically-based work build as mathematical equation is Balan's poem, inspired by Wordworth's wellknown aphorism: "Poetry is emotion recollected in tranquillity". The

\footnotetext{
${ }^{24}$ Yarmarok: Ukrainian writing in Canada Since the Second World War / ed. by J. Balan, Yu. Klenovy. Edmonton, 1987. 355 p.

${ }^{25}$ Nazarenko T. Contemporary visual poetry in Russian and Ukrainian: a critical study. Edmonton, 1999. 365 p.
} 
mathematical-type equation is based on the principle of structural diminution, which operates at the level of the word. In Balan's poem the author's concern for both structural diminution and phonetic patterning provides a visual, as well as an acoustic effect ${ }^{26}$.

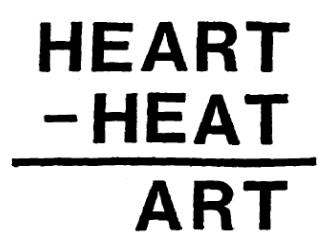

Fig. 15. Jars Balan. Untitled ${ }^{27}$

Mathematical-type poem is also written by M. Soroka (figure 16). This is a number miniature, which is historical exercise. It becomes allegory that is well-known to Ukrainian heart: Acceptance of Christianity in Kyivan Rus, the number of Satan, the year of the end of liberation war, when Bogdan Khmelnytsky signed an agreement with Russia, that actually end of Ukrainian independence for more than 300 years.

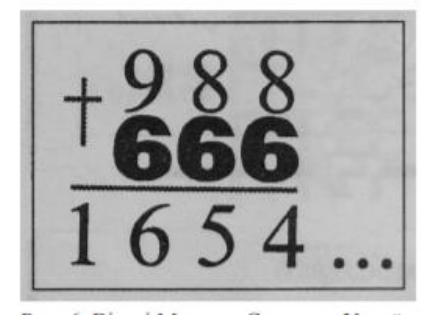

Fig. 16. M. Soroka. Untitled ${ }^{28}$

The structure achieved by arranging the verbal elements in the space of the page according to a text-specific strategy can be considered as visible

${ }^{26}$ Nazarenko T. Contemporary visual poetry in Russian and Ukrainian: a critical study. Edmonton, 1999. 365 p.

27 Балан Я. Визуальное. Черновик. 1999. № 14. URL: http://www.chernovik.org/ main.php?nom=14\&first=18\&cont=yes.

28 Вірші Миколи Сороки. Украӥнська мова $і$ література в школі. 2001. № 43(251) 
idea. The most rewarding way to read such visual poems is to approach them as metapoems.

\section{CONCLUSIONS}

Thus, we can state that the art of visual poetry is an original component of poetic art in general. Visual poetry in the Ukrainian literature is rich in achievements and in fact has opened up broad prospects. It is widely represented in diaspora in North America and was inspired both by Ukrainian culture and literature and Canadian visual poetry. Typically, visual poems are presented as balanced and elegant graphic compositions. Many of these works have a greater power of interpretive vision than traditional texts, since the text exists in an extremely compressed form, reduced to a word or inscription.

As the analysis above shows, the compressed form is quite suitable for the implementation of global, psychological and national issues. Sometimes this form also strengthens the emotional perception of their reading. Poets both build lines in various forms and images and use mathematical equations. Often visual poetry resembles an artistic picture.

So, Ukrainian émigré visual poetry can be considered both as part of Ukrainian poetry with its traditions and as a part of the world concrete poetry of the beginning of $21^{\text {st }}$ century.

\section{SUMMARY}

Visual poetry is the original rather modern part of the poetic art that is the synthesis of literature and fine arts. The aim of this article is to analyze visual poetry in Ukrainian émigré poetry in Canada as a new form of word expression. Among the most well-known authors are Yars Balan, Mykola Soroka, Brian Dedora, Andrew Suknaski etc. They were mostly inspired both by Ukrainian baroque and modern literature and Canadian visual poetry.

Visual poets can be distinguished by the radicalization of the means of communication and be differentiated from other experiences for not semantic values. Graphic-phonetic relations and the substantive use of space as an element of composition maintain a simultaneous dialectic of eye and voice.

The structure achieved by arranging the verbal elements in the space of the page according to a text-specific strategy can be considered as visible idea. This form is quite suitable for the implementation of global, psychological and national issues.

\section{REFERENCES}

1. Балан Я. Визуальное. Черновик. 1999. № 14. URL: http://www.chernovik.org/main.php?nom=14\&first=18\&cont=yes.

2. Величковський I. Твори. Київ : Наукова думка, 1972. 191 с. 
3. Вірші Миколи Сороки. Украӥнська мова $і$ література в школі. 2001. № 43(251).

4. Хрестоматія з української літератури в Канаді: 1897-2000 / упор. : Яр Славутич та М. Шкандрій. Едмонтон : Видавничий комітет «Слова», $2000.632 \mathrm{c}$.

5. Шунь М. Верлібріарій. Абетка : вірші. Київ : Факт, 2006. 405 с.

6. BpNikol. The Captain Poetry Poems. Vancouver : Blewointment Press, 1971. $25 \mathrm{p}$.

7. Nazarenko T. Contemporary visual poetry in Russian and Ukrainian: a critical study. Edmonton, 1999. 365 p.

8. Pineda V. Speaking About Genre: the Case of Concrete Poetry. URL: http://www.ubu.com/papers/pineda.html.

9. Pochynok Yu. Concrete poetry: poetry of fact as a connection between letters and thing. Spheres of Culture. 2012. Vol. 1. P. 82-89.

10. Polishchuk N. Spotting poetry second half of this stage: "Periodic system of words" Ivan Iov. URL: http://www.khnu.km.ua/root/res/2-729541.pdf.

11. Solt M.E. Brazil. URL: http://www.ubu.com/papers/solt/brazil.html.

12. Solt M.E. Concrete Poetry a World View. URL: http://www.ubu.com/papers/solt/intro.html.

13. Yarmarok: Ukrainian writing in Canada Since the Second World War / ed. by J. Balan, Yu. Klenovy. Edmonton, 1987. 355 p.

\section{Information about the author: Nakashydze I. S.,}

Candidate of Philological Sciences, Associate Professor at the Department of Ukrainian Studies Dnipro National University of Railway Transport named after Academician Vsevolod Lazaryan 2, Akademika Lazaryana str., Dnipro, 49010, Ukraine 